\title{
Mantle controls on Kīlauea's magmatic and eruptive behavior
}

\author{
A. J. PIETRUSZKA ${ }^{1}$ \\ ${ }^{1}$ Department of Earth Sciences, University of Hawai ${ }^{i} i$ at \\ Mānoa, Honolulu, HI 96822, USA (apietrus@hawaii.edu)
}

Chemical and isotopic monitoring of lavas from frequently active basaltic volcanoes is a powerful way to decipher magmatic processes (e.g., Rhodes \& Hart, 1995; Pietruszka \& Garcia, 1999; Vlastélic et al., 2009). A key lesson is that aspects of magmatic and volcanic behavior may be directly tied to mantle processes. For example, the most vigorous period of lava effusion in the historical record of Mauna Loa ( 1843 to 1880) correlates with the delivery of a new magma batch from the mantle (Rhodes \& Hart, 1995). This magma batch - characterized by low ${ }^{87} \mathrm{Sr} /{ }^{86} \mathrm{Sr}$ and $\mathrm{Nb} / \mathrm{Y}$, and high ${ }^{206} \mathrm{~Pb} /{ }^{204} \mathrm{~Pb}$ (Rhodes \& Hart, 1995; Weis et al., 2011; this study), each of which peaked from the late 19th to early 20th centuries - was likely produced by a relatively high degree of partial melting of a small-scale compositional heterogeneity within the Hawaiian mantle plume. Lavas from Kîlauea's early historical period (starting in $~ 1823$ ) record a systematic temporal increase in $\mathrm{Nb} / \mathrm{Y}$ (unlike Mauna Loa), and some of the most chemically enriched lavas from the last millennium erupted immediately before and after the 1924 collapse of Halema'uma'u lava lake and explosive eruption. This trend correlates with an increase in ${ }^{206} \mathrm{~Pb} /{ }^{204} \mathrm{~Pb}$ and decrease in ${ }^{87} \mathrm{Sr} /{ }^{86} \mathrm{Sr}$ until $\sim 1921$. Modeling suggests that differences in the composition of the mantle source forced a factor of $\sim 2$ decrease in the degree of partial melting at Kîlauea. This change likely resulted from a smaller amount of ancient recycled oceanic crust in the more depleted, and thus, more refractory, mantle source of the early 20th century Kîlauea lavas (Pietruszka et al., 2013). These mantle-driven processes at Kîlauea led to a decline in the magma supply rate, a major disruption of the volcano's summit reservoir, and, for at least a decade prior to 1924 , crustal contamination at or below the base of the volcanic edifice $(>10 \mathrm{~km})$. Isotopic heterogeneity in ${ }^{206} \mathrm{~Pb} /{ }^{204} \mathrm{~Pb}$ (Pietruszka et al., 2019) and ${ }^{87} \mathrm{Sr} /{ }^{86} \mathrm{Sr}$ (this study) for Kīlauea lavas from 1912 to 1954 require inefficient mixing as small batches of contaminated magma were delivered to the remnants of the summit reservoir. The nearly contemporaneous fluctuation in ${ }^{87} \mathrm{Sr} /{ }^{86} \mathrm{Sr}$ and ${ }^{206} \mathrm{~Pb} /{ }^{204} \mathrm{~Pb}$ at both Kīlauea and Mauna Loa implies that one or more similar (but not identical) mantle heterogeneities were processed separately through the melting region of each volcano (creating differences in $\mathrm{Nb} / \mathrm{Y}$ ). The isotopic link between lavas erupted $\sim 30 \mathrm{~km}$ apart supports the idea of a mantle control on the magmatic and eruptive behavior of the two most active Hawaiian volcanoes. 